\section{Managing Phosphorus for Citrus Yield and Fruit Quality in Developing Orchards}

\author{
Thomas A. Obreza ${ }^{1}$ \\ Soil and Water Science Department, University of Florida, P.O. Box 110290, \\ Gainesville, FL 32611
}

\author{
Robert E. Rouse and Kelly T. Morgan \\ University of Florida, Southwest Florida Research and Education Center, \\ 2686 State Road 29 North, Immokalee, FL 34142
}

Additional index words. phosphorus nutrition, soil test calibration, phosphorus fertilization

\begin{abstract}
No calibrated phosphorus (P) soil test exists to guide Florida citrus fertilization. Applying $P$ fertilizer to citrus when it is not needed is wasteful and may cause undesirable $P$ enrichment of adjacent surface water. The objective of this study was to establish guidelines for $P$ management in developing Florida grapefruit (Citrus paradisi Macf.) and orange (Citrus sinensis L. Osb.) orchards by determining the effect of $P$ fertilizer rate on soil test $P$ and subsequently calibrating a $P$ soil test for citrus yield and fresh fruit quality. Two orchards were planted on sandy soil with $3 \mathrm{mg} \cdot \mathrm{kg}^{-1}$ (very low) Mehlich 1 soil test $P$. In Years 1 through 3, P fertilization increased soil test $P$ up to $102 \mathrm{mg} \cdot \mathrm{kg}^{-1}$ (very high). In Years 4 through 7, canopy volume, yield, and fruit quality did not respond to available soil $P$ as indexed by soil testing. As tree size and fruit production increased, leaf $P$ was below optimum where soil test $P$ was below $13 \mathrm{mg} \cdot \mathrm{kg}^{-1}$ (grapefruit) or $31 \mathrm{mg} \cdot \mathrm{kg}^{-1}$ (oranges). Total $P$ in the native soil at planting was $\approx 42 \mathrm{mg} \cdot \mathrm{kg}^{-1}$, which was apparently available enough to support maximum tree growth, fruit yield, and fruit quality for the first 7 years after planting. Trees were highly efficient in taking up $P$ from a soil considered very low in available $P$. Citrus producers can likely refrain from applying $P$ fertilizer to young trees on Florida sandy soils if soil test $P$ is very high or high and probably medium as well.
\end{abstract}

Citrus orchards occupy more than 280,000 ha in Florida. Soils planted to citrus require intensive nutrient management to maximize fruit yield and quality. Traditionally, orchards receive $\approx 40 \mathrm{~kg}$ phosphorus $(\mathrm{P})$ per ha at planting followed by applications of up to $100 \mathrm{~kg} \cdot \mathrm{ha}^{-1} \mathrm{P}$ per year until they enter the fruitbearing years after age 4 . At this point, fertilization diminishes to an average of $20 \mathrm{~kg} \cdot \mathrm{ha}^{-1}$ $\mathrm{P}$ per year, but some growers apply up to $50 \mathrm{~kg} \cdot \mathrm{ha}^{-1} \mathrm{P}$ per year (Tucker et al., 1990).

Excessive $\mathrm{P}$ fertilization has lowered orange juice soluble solids (Anderson, 1966) and delayed external color development (Koo, 1988). In Florida, the surface layers of some acidic, poorly drained soils planted to citrus are composed of stripped quartz sands that have little capacity to retain soluble $\mathrm{P}$, so the potential for $\mathrm{P}$ leaching exists when the orchard is drained (He et al., 1999, 2006; Li et al., 1999; Zhang et al., 2002). Thus, over-

\footnotetext{
Received for publication 18 July 2008. Accepted for publication 15 Aug. 2008.

We thank the Florida Citrus Production Research Advisory Council, the Florida Department of Agriculture and Consumer Services, and the Potash \& Phosphate Institute (now known as the International Plant Nutrient Institute)-Foundation for Agronomic Research for partially funding this study.

${ }^{1}$ To whom reprint requests should be addressed; e-mail obreza@ufl.edu
}

applying $\mathrm{P}$ should also be avoided to prevent potential water quality degradation.

Bearing citrus trees rarely respond to $\mathrm{P}$ fertilizer (Smith, 1954) except when planted on soils with extreme P fixation capacity or soils nearly devoid of P. For example, Cantarella et al. (1992) and Quaggio et al. (1998) observed positive yield responses of 'Valencia' oranges and lemons [C. limon (L.) Burm.] to annual $\mathrm{P}$ fertilizer rates up to 62 $\mathrm{kg} \cdot \mathrm{ha}^{-1} \mathrm{P}$ on a high P-fixing Brazilian soil. In Florida, Spencer (1963) found that $\mathrm{P}$ improved growth of orange trees planted on previously nonfertilized soil but observed a positive response in only 1 of 4 years when 60 $\mathrm{kg} \cdot \mathrm{ha}^{-1} \mathrm{P}$ per year was applied to bearing trees. Anderson (1966) observed an orange yield response to $P$ fertilizer in 3 of 5 years in central Florida where the Bray P1 soil test was near the accepted minimum adequate value of $40 \mathrm{mg} \cdot \mathrm{kg}^{-1}$ (Koo et al., 1984). This result emphasized the need for a calibrated $\mathrm{P}$ soil test for citrus using a common extractant like Mehlich 1.

Soil test data from bearing Florida citrus orchards reflect the ability of many surface soils to retain applied $\mathrm{P}$ to a limited extent. For example, the Bray P1 soil test was $44 \mathrm{mg} \cdot \mathrm{kg}^{-1}$ at the beginning of the Anderson (1966) $\mathrm{P}$ fertilizer experiment, but it increased to 100 $\mathrm{mg} \cdot \mathrm{kg}^{-1}$ after 8 years. Obreza (1993) observed that Mehlich 1 soil test $P$ increased from 15 to $70 \mathrm{mg} \cdot \mathrm{kg}^{-1}$ in a newly planted orchard where a total of $160 \mathrm{~kg} \cdot \mathrm{ha}^{-1} \mathrm{P}$ was applied during the first 3 years after planting. Anderson (1983), Tucker et al. (1990), and Alva (1993) found that soil test $\mathrm{P}$ in a wide range of mature Florida citrus orchards was five to 10 times higher than what would be expected in similar, nonfertilized soils.

No calibrated $P$ soil test exists specifically for Florida citrus orchards. The critical value of Mehlich 1-extractable P currently used (30 $\left.\mathrm{mg} \cdot \mathrm{kg}^{-1}\right)$ was determined for agronomic crop production (Obreza and Morgan, 2008). Environmental concerns about P loss to surface water and grower consideration of nutritional effects on citrus yield and fruit quality emphasize the importance of judiciously using $\mathrm{P}$ fertilizer. The objective of this experiment was to establish guidelines for $\mathrm{P}$ management in developing Florida grapefruit and orange orchards by determining the effect of $\mathrm{P}$ fertilizer rate on soil test $\mathrm{P}$ and subsequently calibrating a $\mathrm{P}$ soil test for citrus yield and fresh fruit quality.

\section{Materials and Methods}

This experiment was conducted in a new citrus orchard planted on a previously noncultivated soil at the University of Florida, Southwest Florida Research and Education Center in Immokalee, FL. The poorly drained Immokalee fine sand (sandy, siliceous, hyperthermic Arenic Haplaquod) at the site is typical of soils used to produce citrus in south Florida (Obreza and Collins, 2002). After clearing native vegetation in 1994, the land was prepared for citrus planting in 1995 by first leveling and then constructing parallel $15.3-\mathrm{m}$ wide beds separated by $0.9-\mathrm{m}$ deep furrows (swales) to enhance surface drainage. After bed formation, organic matter in the top $0.3 \mathrm{~m}$ of soil averaged $1.7 \%$. The top $15 \mathrm{~cm}$ of soil was limed to $\mathrm{pH} 6.5$ and the site remained fallow for 2 years. In Nov. 1997, 275 'Flame' grapefruit (Citrus paradisi Macf.) and 273 'Hamlin' orange (Citrus sinensis L. Osb.) trees budded to Swingle citrumelo rootstock (Citrus paradisi $\times$ Poncirus trifoliata $\mathrm{L}$.) were planted in double rows on the beds. Rows were $6.7 \mathrm{~m}$ apart across the top of the beds and in-row tree spacing was $4.6 \mathrm{~m}$ (326 trees/ha). Standard nursery-grown grapefruit and orange trees were planted in separate, adjacent orchards. An installed microirrigation system had one microsprinkler $\left(60 \mathrm{~L} \cdot \mathrm{h}^{-1}\right.$ flow rate, $3.7-\mathrm{m}$ diameter wetting pattern) per tree placed adjacent to the trunk.

No fertilizer was applied to the orchards during the first 11 months after planting as a result of lack of fertilizer response previously observed with newly planted citrus trees in a similar locale (Obreza, 1990). In Aug. 1998, a general sampling of the top $20 \mathrm{~cm}$ of orchard soil revealed that Mehlich 1 soil test $P$ averaged $3 \mathrm{mg} \cdot \mathrm{kg}$, which fell in the very low range according to University of Florida soil test interpretations (Mylavarapu et al., 2007). Nitrogen and potassium (K) fertilizers were applied to assure that nutrient availability was neither deficient nor excessive with 
respect to tree growth, fruit production, and fruit quality. Application rates and timing were within University of Florida guidelines (Obreza and Morgan, 2008). Nitrogen fertilization began with $49 \mathrm{~kg} \cdot \mathrm{ha}^{-1} \mathrm{~N}$ in Year 2 after planting (1999) and gradually increased to $202 \mathrm{~kg} \cdot \mathrm{ha}^{-1} \mathrm{~N}$ in Year 5 after planting and beyond. Potassium fertilizer rates ranged from 93 to $186 \mathrm{~kg} \cdot \mathrm{ha}^{-1} \mathrm{~K}$ per year.

Four rates of $P$ fertilizer $(0,24,49$, and 98 $\mathrm{kg} \cdot \mathrm{ha}^{-1} \mathrm{P}$ per year) were applied by plot to establish a range of soil test $P$ throughout the orchard. There were 10 replications of each treatment in a randomized complete block design. A plot consisted of three consecutive trees in a row. Citrus response data were collected from the center tree, whereas the outside two trees buffered the potential influence of adjacent plots. Annual P rates were applied once per year for the first 3 years of the experiment (Oct. 1998, May 1999, and Mar. 2000) using concentrated superphosphate $(0 \mathrm{~N}-20 \mathrm{P}-0 \mathrm{~K})$. Fertilizer was spread by hand along the tree row in a continuous band covering the width of the canopy $(\approx 2 \mathrm{~m})$ simulating the pattern of a mechanical fertilizer applicator used in commercial orchards.

Other nutrients applied to avoid potential deficiencies included: 1) soil applications of fritted zinc, iron, manganese, copper, and boron in Dec. 1999 and Mar. 2000; 2) foliar spray application of a nitrogen-iron-manganesezinc mixture each summer from 2000 onward; 3) foliar spray application of magnesiummanganese-copper-iron-boron-molybdenum in Apr. 2002; and 4) a magnesium sulfate soil application in May 2003. Irrigation was required during dry weather in the spring and fall. The volume of water applied at each irrigation was based on the root zone waterholding capacity of $0.08 \mathrm{~cm}^{-3} \cdot \mathrm{cm}^{-3}$ of soil to minimize leaching. Irrigation water was groundwater containing $0.05 \mathrm{mg} \cdot \mathrm{L}^{-1} \mathrm{P}$. Roughly 1 $\mathrm{kg} \cdot \mathrm{ha}^{-1} \mathrm{P}$ was applied with irrigation water each year, which was considered a negligible $\mathrm{P}$ input. A continuous weed-free band $\approx 4 \mathrm{~m}$ wide was maintained beneath the tree row canopy by applying bromacil, diuron, and glyphosate herbicides as needed. Grass growing in bed middles and drainage furrows prevented soil erosion. Grass was mowed as needed and the clippings were left on the surface. Citrus oil 435 was sprayed on the tree canopy once each summer to suppress mites and fungal diseases.

An annual cycle of plot soil sampling began in Summer 1999. A soil sample comprised six cores $2 \mathrm{~cm}$ in diameter and $20 \mathrm{~cm}$ deep removed in an evenly spaced circular pattern around the canopy edge of the center tree in each plot. The soil was air-dried and passed through a 2-mm screen before determining Mehlich 1 soil test P (Soil and Plant Analysis Council, Inc., 1999). Ten 6-monthold spring growth leaves from nonfruiting twigs were sampled in a circular pattern around each center tree when soil samples were taken. Leaves were dried, ground, and analyzed for total $\mathrm{N}, \mathrm{P}, \mathrm{K}, \mathrm{Ca}$, and $\mathrm{Mg}$ concentrations (Southern Extension and Research Activity Group, 1992). In 2005, 75-cm deep soil cores were removed from eight plots within each orchard (two replicates of each of the four $P$ rates). Cores were separated into three $25-\mathrm{cm}$ increments and total $\mathrm{P}$ was measured with an ashing procedure (Anderson, 1976).

Tree canopy volume was estimated from measurements of canopy width and tree height [canopy volume $=4 / 3(\pi)$ (tree height) (canopy radius) $\left.^{2}\right]$. Fruit production was measured from 2001 (fourth year after planting) onward. Oranges were harvested in December and grapefruits were harvested 1 month later each season. Fruits from the center tree in each plot were hand-picked and weighed collectively. Juice was extracted from a random $0.018-\mathrm{m}^{3}$ subsample of fruit using a commercial extractor (FMC Corp., Agricultural Machinery Div., Jonesboro, AR). Quality parameters included percentage juice per fruit, total soluble solids (TSS) measured with a Brix hydrometer (Wardowski et al., 1979), acid concentration measured by alkali titration (Wardowski et al., 1979), and TSSto-acid ratio. For oranges, TSS yield in $\mathrm{g} \cdot \mathrm{kg}^{-1}$ fruit and $\mathrm{kg} /$ tree were calculated from fruit yield, percentage juice, and TSS in the juice. Because fresh fruit characteristics are important for grapefruit, an additional 10-fruit subsample was taken from each plot to measure size (diameter and height), shape, and peel thickness. Fruit shape (degree of flatness, a preferred characteristic) was evaluated by calculating the height-to-diameter ratio. Fruits were cut in half at the widest point, peel thickness was measured at opposite sides of the grapefruit half, and the two values were averaged.

Response of soil test $\mathrm{P}$ to fertilizer rate was evaluated using linear regression (Systat Software, Inc., 2006). Phosphorus soil test calibration was attempted by relating tree size, fruit yield, leaf tissue P concentration, and fruit quality variables measured from each plot in a given year to soil test $\mathrm{P}$ measured in late summer of the previous year. The calibration method used was the Cate-Nelson procedure (Dahnke and Olson, 1990), which is an iterative statistical procedure for separating crop response data into

Table 1. Annual measurements of Mehlich 1 soil test phosphorus (P) in two citrus orchards as affected by $\mathrm{P}$ fertilizer rate ${ }^{z}$.

\begin{tabular}{|c|c|c|c|c|c|}
\hline \multirow{2}{*}{$\begin{array}{l}\text { P fertilizer rate } \\
\left(\mathrm{kg} \cdot \mathrm{ha}^{-1}\right)\end{array}$} & \multicolumn{5}{|c|}{ Mean Mehlich 1 soil test P (SD) } \\
\hline & 1999 & 2000 & 2001 & 2002 & 2003 \\
\hline & \multicolumn{5}{|c|}{ Grapefruit orchard } \\
\hline 0 & $3(2)$ & $6(2)$ & $6(3)$ & $3(2)$ & $2(1)$ \\
\hline 24 & $20(11)$ & $24(15)$ & $13(6)$ & $7(2)$ & $3(2)$ \\
\hline 49 & $18(13)$ & $29(13)$ & $22(7)$ & $10(5)$ & $6(4)$ \\
\hline 98 & $35(13)$ & $82(34)$ & $34(17)$ & $23(16)$ & $13(9)$ \\
\hline Linear regression & $* * *$ & $* * *$ & $* * *$ & $* * *$ & $* * *$ \\
\hline \multicolumn{6}{|c|}{ Orange orchard } \\
\hline 24 & $14(7)$ & $36(24)$ & $24(15)$ & $20(7)$ & $6(4)$ \\
\hline 49 & $19(10)$ & $70(25)$ & $43(14)$ & $25(11)$ & $13(7)$ \\
\hline 98 & $39(10)$ & $102(30)$ & $65(17)$ & $50(23)$ & $26(12)$ \\
\hline Linear regression & $* * *$ & $* * *$ & $* * *$ & $* * *$ & $* * *$ \\
\hline
\end{tabular}

${ }^{z}$ Initial soil test $\mathrm{P}$ in 1998 was $3 \mathrm{mg} \cdot \mathrm{kg}^{-1}$. Univ. of Florida $\mathrm{P}$ soil test interpretations in $\mathrm{mg} \cdot \mathrm{kg}^{-1} \mathrm{P}$ soil are: less than $10=$ very low; 10 to $15=$ low; 16 to $30=$ medium; 31 to $60=$ high; greater than $60=$ very high . ${ }^{y}$ Annual $P$ fertilizer rates were applied from 1998 through 2000.

${ }^{* * *}$ Significant at $P<0.001$. two classes based on maximizing the class sum of squares in a one-way analysis of variance. Using this procedure, one finds quantitatively the best division from the point of view of maximizing mean differences among classes (Nelson and Anderson, 1977). The soil test value that separates the two classes is defined as the critical value of soil test P.

\section{Results and Discussion}

Annual $\mathrm{P}$ fertilizer applications from 1998 to 2000 increased soil test P (Table 1). annual $\mathrm{P}$ fertilizer rate each year resulted in significant positive relationships with $R^{2}$ ranging from 0.88 to 0.99 for the grapefruit orchard and from 0.82 to 0.99 for the orange orchard. In the third year after planting, the 24 and $49 \mathrm{~kg} \cdot \mathrm{ha}^{-1} \mathrm{P}$ annual application rates elevated soil test $\mathrm{P}$ to medium (grapefruit) or high (oranges), and the $98 \mathrm{~kg} \cdot \mathrm{ha}^{-1} \mathrm{P}$ rate raised it to very high in both orchards. At this point, $\mathrm{P}$ fertilization was suspended because the objective of establishing a wide range of soil test $\mathrm{P}$ among plots was achieved.

Soil test $\mathrm{P}$ began to decrease in the fourth year after planting (2001) (Table 1). By the sixth year (2003), soil test $\mathrm{P}$ had returned to values almost identical to those measured 4 months after the first $\mathrm{P}$ fertilizer application in 1999. Rhue and Everett (1987), Harris et al. (1996), He et al. (1999), Li et al. (1999), and Zhang et al. (2002) have shown the limited ability of some south Florida sandy soils to hold P. Thus, residual P fertilizer was either taken up by the trees or was leached below the depth of soil sampling. Indeed, measurements of total P in the top $25 \mathrm{~cm}$ of soil in 2005 showed little influence of previous $\mathrm{P}$ fertilizer application. The top $25-\mathrm{cm}$ layer contained $31 \mathrm{mg} \cdot \mathrm{kg}^{-1}$ total $\mathrm{P}$ in plots not fertilized with $\mathrm{P}$ compared with $34 \mathrm{mg} \cdot \mathrm{kg}^{-1}$ where it had been applied. The $50-$ to $75-\mathrm{cm}$ layer beneath nonfertilized plots contained $21 \mathrm{mg} \cdot \mathrm{kg}^{-1}$ total $\mathrm{P}$ compared with $32 \mathrm{mg} \cdot \mathrm{kg}^{-1}$ total $\mathrm{P}$ under fertilization, suggesting some accumulation at that depth. Linear regression of mean soil test $\mathrm{P}$ on 
Grapefruit trees grew more rapidly than orange trees during the experiment although all trees were managed the same way. Mean canopy volume of 5-year-old grapefruit trees were approximately three times larger than orange trees (Table 2). Although grapefruit trees are inherently more vigorous, this aspect does not fully explain the size difference. A contributing factor may have been a freeze that occurred on 6 Jan. 1999, when the air temperature fell below $0{ }^{\circ} \mathrm{C}$ for $7 \mathrm{~h}$ with a minimum of $-1.6^{\circ} \mathrm{C}$. Some split bark indicating tree damage was observed across the orchards, but the amount of damage was not quantified because it appeared to be minor and uniformly distributed. However, although the grapefruit trees continued to grow normally during the first season after the freeze, the orange trees grew much less, suggesting that they were more severely affected by cold weather. Mean canopy volumes in Sept. 1999 were 4.30 and $0.75 \mathrm{~m}^{3}$ for the grapefruit and orange trees, respectively. The orange trees began to grow normally during the next season, but they remained 1 to 2 years behind relative to typical tree size. At the end of the orange orchard's seventh year, it contained healthy, bearing trees that were smaller than usual for their age.

Tree canopy volume was unaffected by $\mathrm{P}$ availability expressed as soil test $\mathrm{P}$ (Table 2 ). The trees showed a marked lack of sensitivity to $\mathrm{P}$ on a previously uncultivated soil considered P-deficient. However, at 5 years, they had grown mostly vegetatively, building a canopy without the $\mathrm{P}$ sink of heavy fruit production. The grapefruit trees produced a mean fruit yield of $20 \mathrm{~kg} /$ tree in Year 4 and $25 \mathrm{~kg} /$ tree in Year 5 , which was $\approx 10 \%$ of expected mature tree production (i.e., 10+ years old). Mean orange tree yield in Year 5 was $6 \mathrm{~kg} /$ tree, which was $\approx 5 \%$ of the yield mature trees typically produce.

The leaf $\mathrm{P}$-soil test $\mathrm{P}$ relationship was the strongest of any observed in the soil test calibration process (Figs. 1 and 2). In the grapefruit orchard, the Cate-Nelson procedure indicated that soil test $\mathrm{P} 13 \mathrm{mg} \cdot \mathrm{kg}^{-1}$ or greater maintained optimum or higher leaf $\mathrm{P}$ in 4- to 7-year-old trees. Of the 42 grapefruit leaf $\mathrm{P}$ values that were below optimum, 39 were associated with soil test $\mathrm{P}$ below the critical value. The Cate-Nelson model explained $42 \%$ of relative leaf $P$ concentration variability, which is reasonably good considering the wide variety of innate and external factors that affect individual citrus tree growth (Jackson, 1991). In the orange orchard, Cate-Nelson critical soil test $\mathrm{P}$ was $31 \mathrm{mg} \cdot \mathrm{kg}^{-1}$. Of the nine orange leaf $P$ values that were below optimum, eight were associated with soil test $\mathrm{P}$ below the critical value. The Cate-Nelson model in this case explained only $21 \%$ of leaf $\mathrm{P}$ variability, most likely because the orange trees were smaller with considerably less $\mathrm{P}$ demand compared with the grapefruit trees.

Fruit yield was much less sensitive to soil test $P$. Correlations of annual fruit yields from 2001 to 2004 (grapefruit) and 2003 to 2004 (oranges) with soil test $\mathrm{P}$ from the previous year were not useful to estimate a critical value because Cate-Nelson $R^{2}$ was 0.11 or less (Table 2). Part of the reason for this result was the naturally occurring, wide tree-to-tree yield variation that is typical of juvenile citrus trees (Jackson, 1991). A longer-term analysis of yield versus soil test $\mathrm{P}$ did not improve the correlation. For example, when

cumulative yield from 2001 through 2004 was compared with soil test P from 2000, Cate-Nelson $R^{2}$ values were 0.09 for grapefruit and 0.20 for oranges. The highest cumulative grapefruit and orange yields from single trees were 294 and $104 \mathrm{~kg}$, respectively. These yields contained $\approx 50$ and $18 \mathrm{~g}$ of $\mathrm{P}$, respectively. Apparently, the amount of

Table 2. Mean values of tree size, fruit yield, and fruit quality measurements and their suitability for soil test correlation based on Cate-Nelson $R^{2 z}$.

\begin{tabular}{|c|c|c|}
\hline Response variable & Mean (SD) & $\begin{array}{c}\text { Cate-Nelson } R^{2} \text { for correlation } \\
\text { between response variable } \\
\text { and soil test } \mathrm{P}\end{array}$ \\
\hline \multicolumn{3}{|l|}{ Grapefruit orchard } \\
\hline Canopy volume, $2002\left(\mathrm{~m}^{3}\right)$ & $21.6(6.1)$ & 0.17 \\
\hline Yield, $2001(\mathrm{~kg} /$ tree $)$ & $44.4(37.9)$ & 0.11 \\
\hline Yield, 2002 (kg/tree) & $55.8(40.7)$ & 0.10 \\
\hline Yield, 2003 (kg/tree) & $58.7(19.6)$ & 0.13 \\
\hline Yield, 2004 (kg/tree) & $104.7(35.2)$ & 0.04 \\
\hline Juice TSS ( ${ }^{\circ}$ Brix $)$ & $9.00(1.05)$ & 0.11 \\
\hline Juice acid $\left(\mathrm{g} \cdot \mathrm{kg}^{-1}\right)$ & $9.9(1.0)$ & 0.02 \\
\hline Juice TSS-to-acid ratio & $9.1(0.6)$ & 0.05 \\
\hline Fruit diameter (mm) & $94(9)$ & 0.06 \\
\hline Fruit height-to-diameter ratio & $0.93(0.03)$ & 0.20 \\
\hline Peel thickness (mm) & $5.9(0.8)$ & 0.12 \\
\hline \multicolumn{3}{|l|}{ Orange orchard } \\
\hline Canopy volume, $2002\left(\mathrm{~m}^{3}\right)$ & $7.5(2.8)$ & 0.16 \\
\hline Yield, 2003 (kg/tree) & $13.4(10.4)$ & 0.06 \\
\hline Yield, 2004 (kg/tree) & $25.4(7.8)$ & 0.07 \\
\hline Juice TSS ( ${ }^{\circ}$ Brix $)$ & $9.75(1.43)$ & 0.01 \\
\hline Juice acid $\left(\mathrm{g} \cdot \mathrm{kg}^{-1}\right)$ & $5.1(0.8)$ & 0.00 \\
\hline Juice TSS-to-acid ratio & $19.4(3.6)$ & 0.03 \\
\hline Juice quality (g TSS/kg fruit) & $52.8(8.5)$ & 0.00 \\
\hline Fruit diameter $(\mathrm{mm})$ & $69(4)$ & 0.00 \\
\hline
\end{tabular}

${ }^{\mathrm{z}}$ Fruit quality measurement means were calculated from combined data of all years in which fruit were harvested.

TSS $=$ total soluble solids.

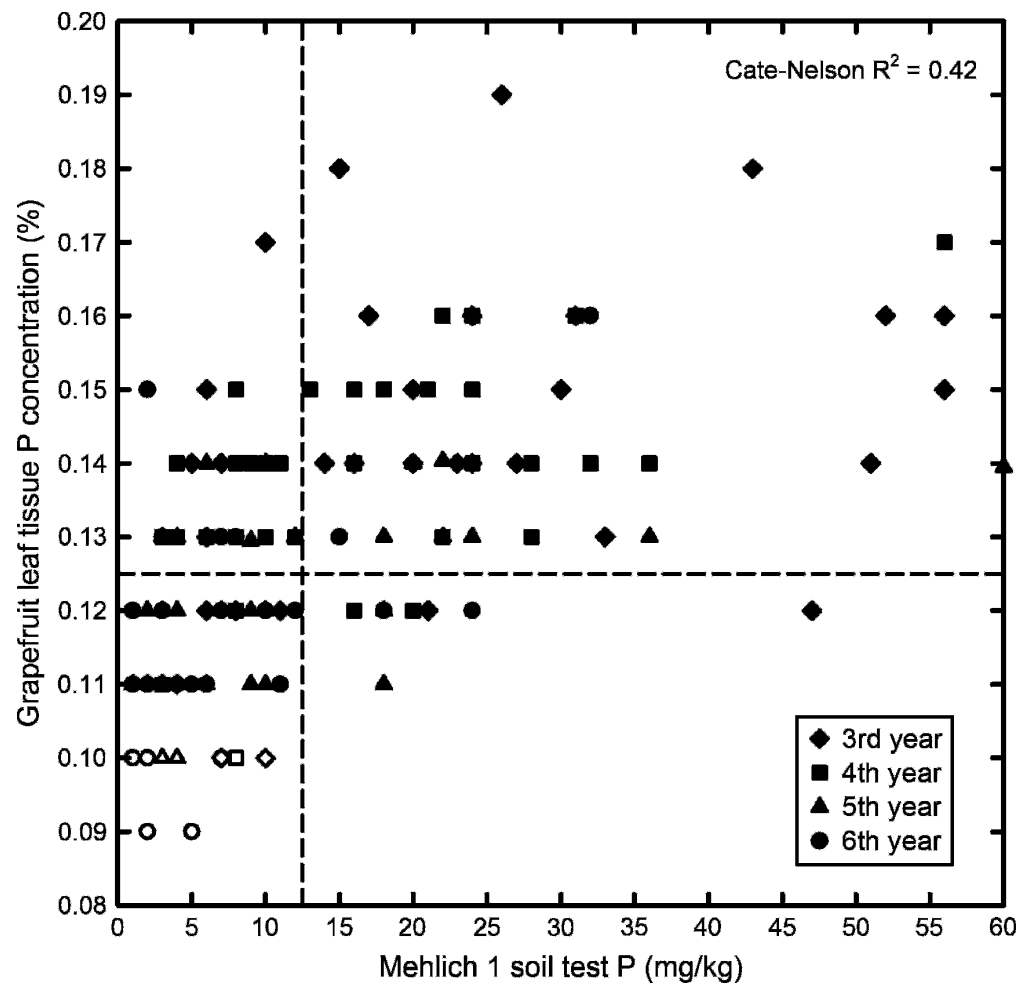

Fig. 1. Relationship of phosphorus (P) concentration in 2002 to 2005 spring growth grapefruit leaves to Mehlich 1 soil test $\mathrm{P}$ measured in summer of the previous year. The vertical dashed line indicates the Cate-Nelson critical soil test $P$ value. Leaf $P$ interpretations are: less than $0.09 \%=$ deficient; $0.09 \%$ to $0.11 \%=$ low; $0.12 \%$ to $0.16 \%=$ optimum; $0.17 \%$ to $0.29 \%=$ high; greater than $0.29 \%=$ excessive . 


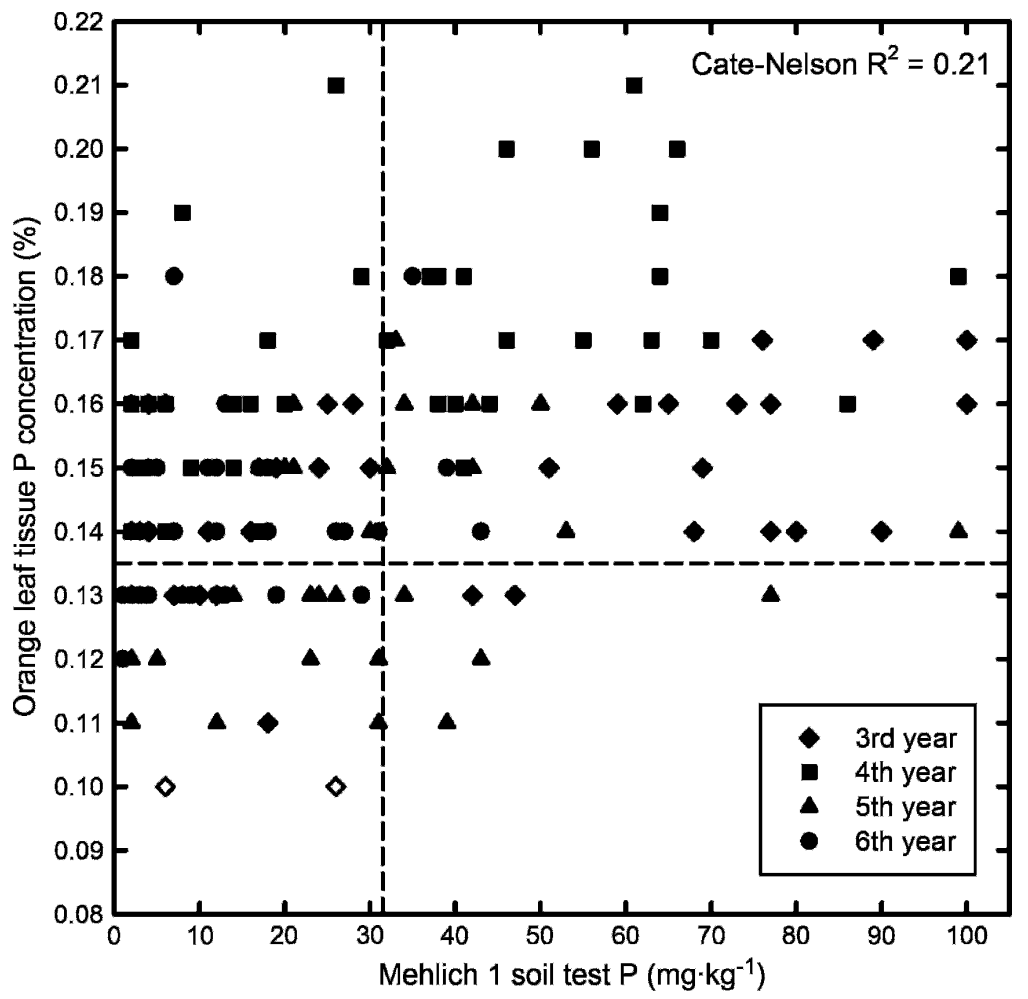

Fig. 2. Relationship of phosphorus concentration in 2002 to 2005 spring growth orange leaves to Mehlich 1 soil test $\mathrm{P}$ measured in summer of the previous year. The vertical dashed line indicates the Cate-Nelson critical soil test $\mathrm{P}$ value. Leaf $\mathrm{P}$ interpretations are: less than $0.09 \%=$ deficient; $0.09 \%$ to $0.11 \%=$ low; $0.12 \%$ to $0.16 \%=$ optimum; $0.17 \%$ to $0.29 \%=$ high; greater than $0.29 \%=$ excessive.

$\mathrm{P}$ required for the 4- to 7-year-old trees to produce fruit was satisfied by the amount available from the native soil.

Fruit and juice quality measurements were typical of fruit produced by young citrus trees, but little to none of their variation could be attributed to differences in soil test $\mathrm{P}$ (Table 2). The largest calculated Cate-Nelson $R^{2}$ value $(0.20)$ was for the relationship between grapefruit shape and soil test $\mathrm{P}$, suggesting rounder fruits at soil test $\mathrm{P}$ below $5 \mathrm{mg} \cdot \mathrm{kg}^{-1}$ and flatter fruits above this value.
In a summary of nutritional effects on fruit and juice quality in Florida, Koo (1988) indicated that increasing $\mathrm{P}$ nutrition decreases juice acid, increases TSS-to-acid ratio, and decreases peel thickness. No significant relationship between these quality factors and soil test $\mathrm{P}$ was found in this study.

The lack of citrus yield or fruit quality response to soil $\mathrm{P}$ availability as indexed by the Mehlich 1 soil test was surprising considering that the orchards were planted on a native, low-P south Florida sandy soil. The site was chosen because it provided a reasonable chance of inducing $P$ deficiency in young citrus trees if $\mathrm{P}$ fertilization was withheld. The results prompted a subsequent investigation to determine if the native soil contained enough total $\mathrm{P}$ to support the observed growth of nonfertilized trees by comparing the total amount of $\mathrm{P}$ accumulated by the trees as they grew with the total amount that existed in the root zone.

Annual $\mathrm{P}$ distribution in the tree, fruit, and root zone soil were estimated for the largest and highest-yielding grapefruit and orange trees that did not receive $\mathrm{P}$ fertilizer, assuming that: 1) $P$ deposited on the soil surface in tree and weed residues (e.g., dropped leaves, twigs, fruit; dead roots) was recycled back to the root zone through soil organic matter; 2) the only $\mathrm{P}$ exported from the tree-soil system was in the harvested fruit; and 3) the $\mathrm{P}$ in the trees at planting and $\mathrm{P}$ from external sources like irrigation water or atmospheric deposition were negligible (Table 3). A linear relationship between citrus tree canopy volume and total $\mathrm{P}$ in the tree (including roots) developed by K. T. Morgan (unpublished data) was used to track total $\mathrm{P}$ accumulation as the trees grew: total P $(\mathrm{g})=(0.94)$ [canopy volume $\left.\left(\mathrm{m}^{3}\right)\right]+15.1$. Fruit $\mathrm{P}$ was accounted for by multiplying annual yield $(\mathrm{kg})$ by the mean $\mathrm{P}$ concentration of fresh citrus fruits (0.017\%; Paramasivam et al., 2000). The annual active root zone volume was estimated to be a cylinder of soil with diameter equal to the tree canopy width and depth of $0.25 \mathrm{~m}$. (This estimate was conservative because citrus roots were consistently observed extending laterally beyond the canopy edge.) The total $\mathrm{P}$ pool within the root zone was estimated by first determining the soil mass using a bulk density of $1.5 \mathrm{~g} \cdot \mathrm{cm}^{-3}$ and then multiplying by $42 \mathrm{mg} \cdot \mathrm{kg}^{-1} \mathrm{P}$, which was the assumed total soil $\mathrm{P}$ concentration at planting based on our initial Mehlich 1 soil tests and a relationship we established between Mehlich $1 \mathrm{P}$ and total $\mathrm{P}$. As the trees began to produce fruit, we accounted for the mass of $\mathrm{P}$ exported in

Table 3. Annual estimation of phosphorus $(\mathrm{P})$ in tree, fruit, and root zone soil for the largest grapefruit and orange trees that received no $\mathrm{P}$ fertilizer ${ }^{2}$.

\begin{tabular}{|c|c|c|c|c|c|c|c|}
\hline Year & $\begin{array}{l}\text { Canopy } \\
\text { volume } \\
\left(\mathrm{m}^{3}\right)\end{array}$ & $\begin{array}{l}\text { Total P } \\
\text { in tree } \\
(\mathrm{g})\end{array}$ & $\begin{array}{l}\text { Total P } \\
\text { in fruit } \\
(\mathrm{g})\end{array}$ & $\begin{array}{l}\text { Total P (tree } \\
\text { plus fruit) } \\
\text { (g) }\end{array}$ & $\begin{array}{l}\text { Root zone } \\
\text { volume } \\
\left(\mathrm{m}^{3}\right)\end{array}$ & $\begin{array}{l}\text { Initial total P content of } \\
\text { root zone volume } \\
(\mathrm{g})\end{array}$ & $\begin{array}{l}\text { Relative amount of root } \\
\text { zone } \mathrm{P} \text { taken up }{ }^{\mathrm{u}} \\
\left(\mathrm{g} \cdot \mathrm{g}^{-1}\right)\end{array}$ \\
\hline \multicolumn{8}{|c|}{ Grapefruit } \\
\hline 1999 & 9.9 & 24 & 0 & 24 & 1.7 & 107 & 0.22 \\
\hline 2001 & 33.6 & 47 & 22 & 69 & 3.9 & 246 & 0.29 \\
\hline 2002 & 37.8 & 51 & 27 & 78 & 4.2 & 265 & 0.39 \\
\hline 2003 & 38.0 & 51 & 27 & 78 & 4.2 & 265 & 0.49 \\
\hline 2000 & 4.9 & 20 & 0 & 20 & 1.0 & 63 & 0.32 \\
\hline 2001 & 12.8 & 27 & 6 & 33 & 1.5 & 95 & 0.35 \\
\hline 2002 & 13.1 & 27 & 2 & 29 & 1.7 & 107 & 0.33 \\
\hline 2003 & 15.8 & 30 & 19 & 49 & 2.1 & 132 & 0.43 \\
\hline 2004 & 18.4 & 33 & 16 & 49 & 2.5 & 158 & 0.48 \\
\hline
\end{tabular}

${ }^{2}$ These estimates assume that $\mathrm{P}$ deposited on the soil surface in tree and weed residues was recycled back to the root zone through soil organic matter. The only assumed P export from the system was in harvested fruit. The initial P content of the trees at planting and P from external sources like irrigation water or atmospheric deposition were ignored.

${ }^{y}$ Estimated from a linear regression relating tree canopy volume to total P in the tree (K.T. Morgan, unpublished data).

${ }^{x}$ Estimated by multiplying fruit yield by the mean P concentration in citrus fruits $(0.017 \%$; Paramasivam et al., 2000$)$.

"Estimated as a cylindrical soil volume with diameter equivalent to tree canopy diameter and depth of $0.25 \mathrm{~m}$.

vestimated from soil bulk density of $1.5 \mathrm{~g} \cdot \mathrm{cm}^{-3}$ and total $\mathrm{P}$ concentration of $42 \mathrm{mg} \cdot \mathrm{kg}^{-1}$.

u(P in tree plus cumulative fruit produced $) /($ initial total $\mathrm{P}$ content of root zone $)$. 
harvested fruit by subtracting it from the total $\mathrm{P}$ pool in the root zone.

Comparison of total tree P plus exported fruit $P$ with the mass of potentially available soil $\mathrm{P}$ each year showed that the root zone contained more than enough $\mathrm{P}$ to meet the need of nonfertilized trees through 2004 (Table 3), assuming that a substantial portion of it was plant-available. This premise is not difficult to accept considering the perennial root system of citrus trees and the lack of high P-fixing capacity in the root zone soil. It was estimated that nonfertilized grapefruit trees took up roughly $25 \%$ of total root zone soil $\mathrm{P}$ in the early years. Canopy expansion and fruit production provided additional $\mathrm{P}$ sinks that increased soil $P$ uptake to nearly $60 \%$ of total root zone $\mathrm{P}$ by the end of Year 7. A grapefruit leaf $\mathrm{P}$ concentration drawdown observed in nonfertilized trees (orchard-wide means of $0.15,0.14,0.12$, and $0.11 \% \mathrm{P}$ from 2001 to 2004) could indicate decreasing availability of remaining soil $\mathrm{P}$ and may foreshadow an eventual $\mathrm{P}$ deficiency. It was estimated that nonfertilized orange trees took up less than half of total soil P by 2004 as a result of a smaller canopy and less fruit production. Consequently, a leaf $\mathrm{P}$ concentration drawdown in these trees was not observed (means of $0.15 \%, 0.17 \%, 0.13 \%$, and $0.14 \% \mathrm{P}$ from 2001 to 2004).

\section{Conclusions}

A typical native south Florida soil retained $\mathrm{P}$ fertilizer in the root zone for $\approx 3$ years after it was applied to developing grapefruit and orange orchards. However, young tree growth, yield, and fruit quality were not sensitive to $\mathrm{P}$ fertilizer rate or available soil $\mathrm{P}$ as indexed by the Mehlich 1 soil test. Of the responses measured, leaf $\mathrm{P}$ correlated best with soil test P. As the tree canopy expanded and began to produce fruit, leaf $\mathrm{P}$ drawdown was greater where soil test $\mathrm{P}$ was the lowest (nonfertilized plots) compared with plots where soil test $P$ was higher as a result of fertilizer application, suggesting a lower $\mathrm{P}$ reserve in trees growing on low $\mathrm{P}$ soil. The Cate-Nelson critical value of Mehlich 1 soil test $\mathrm{P}$ to maintain optimum leaf $\mathrm{P}$ in the grapefruit orchard was $13 \mathrm{mg} \cdot \mathrm{kg}^{-1}$, or approximately half of the soil test $P$ value that currently divides the medium and high ranges in Florida. Citrus leaf analysis has been used to evaluate citrus tree nutrition for decades because perennial plants are their own best indicators of nutrient availability. Reference citrus leaf sufficiency values are used worldwide to guide fertilization (Embleton et al., 1973).

Because there was enough available $P$ in the native soil to support maximum tree growth, fruit yields, and fruit quality for the first 7 years after planting, a soil test calibration based on these responses cannot yet be achieved. Based on conservative estimates of potential root zone volume, possibly $50 \%$ to
$60 \%$ of total soil $\mathrm{P}$ was taken up by the largest, highest-yielding trees that received no $\mathrm{P}$ fertilizer. As tree canopy expansion continues, higher fruit yields will increase the amount of $\mathrm{P}$ that is exported from the orchards, and P deficiency may yet develop.

The citrus trees in our experiment were highly efficient in taking up P from a soil considered very low in available P. Citrus producers can likely refrain from applying $\mathrm{P}$ fertilizer to young trees planted on south Florida sandy soils if soil test $\mathrm{P}$ is very high or high and probably medium as well. However, $\mathrm{P}$ may need to be applied in response to annual soil and/or leaf $P$ tests as trees continue to grow and increase fruit production. Tracking soil and leaf $\mathrm{P}$ as the trees grow is a less expensive, more environmentally responsible way to determine if $\mathrm{P}$ fertilizer is needed compared with regular maintenance applications.

\section{Literature Cited}

Alva, A.K. 1993. Comparison of Mehlich 3, Mehlich 1, ammonium bicarbonate-DTPA, $1.0 \mathrm{M}$ ammonium acetate, and $0.2 \mathrm{M}$ ammonium chloride for extraction of calcium, magnesium, phosphorus, and potassium for a wide range of soils. Commun. Soil Sci. Plant Anal. 24:603-612.

Anderson, C.A. 1966. Effects of phosphate fertilizer on yield and quality of 'Valencia' oranges. Proc. Fla. State Hort. Soc. 79:36-40.

Anderson, C.A. 1983. Comparison of Mehlich I and Bray I soil tests for phosphorus in citrus groves. Soil Crop Sci. Soc. Fla. Proc 42:146-149.

Anderson, J.M. 1976. An ignition method for determination of total phosphorus in lake sediments. Water Res. 10:329-331.

Cantarella, H., J.A. Quaggio, O.C. Bataglia, and B. van Raij. 1992. Response of citrus to NPK fertilization in a network of field trials in Sao Paulo State, Brazil, p. 607-612. In: Proc. Int. Soc. Citriculture. Int. Citrus Congr., Acireale, Italy.

Dahnke, W.C. and R.A. Olson. 1990. Soil test correlation, calibration, and recommendation, p. 45-71. In: Westerman, R.L. (ed.). Soil testing and plant analysis. 3rd Ed. SSSA, Madison, WI.

Embleton, T.W., W.W. Jones, C.K. Labanauskas, and W. Reuther. 1973. Leaf analysis as a diagnostic tool and guide to fertilization, p. 183-210. In: Reuther, W. (ed.). The citrus industry, Vol. III. Univ. of California, Berkeley, CA

Harris, W.G., R.D. Rhue, G. Kidder, R.B. Brown, and R. Littell. 1996. Phosphorus retention as related to morphology of sandy coastal plain soil materials. Soil Sci. Soc. Amer. J. 60:15131521.

He, Z.L., A.K. Alva, Y.C. Li, D.V. Calvert, and D.J. Banks. 1999. Sorption-desorption and solution concentration of phosphorus in a fertilized sandy soil. J. Environ. Qual. 28:1804-1810.

He, Z.L., M.K. Zhang, P.J. Stoffella, X.E. Yang, and D.J. Banks. 2006. Phosphorus concentrations and loads in runoff water under crop production. Soil Sci. Soc. Amer. J. 70:1807-1816.

Jackson, L.K. 1991. Citrus growing in Florida. 3rd Ed. Univ. of Florida Press, Gainesville, FL.

Koo, R.C.J. 1988. Fertilization and irrigation effects on fruit quality, p. 35-42. In: Ferguson, J.J. and W.F. Wardowski (eds.). Factors affect- ing fruit quality-Citrus short course. Proc. Univ. of Fla. Coop. Ext. Serv., Gainesville, FL. Koo, R.C.J., C.A. Anderson, I. Stewart, D.P.H. Tucker, D.V. Calvert, and H.K. Wutscher. 1984. Recommended fertilizers and nutritional sprays for citrus. Fla. Agr. Expt. Sta. Bul. 536D.

Li, Y.C., A.K. Alva, and D.V. Calvert. 1999. Transport of phosphorus and fractionation of residual phosphorus in various horizons of a Spodosol. Water Air Soil Pollut. 109:303-312.

Mylavarapu, R., D. Wright, G. Kidder, and C.G. Chambliss. 2007. UF/IFAS standard fertilization recommendations for agronomic crops Florida. Fla. Coop. Ext. Serv. SL129. 17 Sept. 2008. $<$ http://edis.ifas.ufl.edu/SS163>.

Nelson, L.R. and R.L. Anderson. 1977. Partitioning of soil test-crop response probability. In: Peck, T.R., J.T. Cope, Jr., and D.A. Whitney (eds.). Soil testing: Correlating and interpreting the analytical results. Amer. Soc. Agron. Spec. Pub. No. 29

Obreza, T.A. 1990. Young 'Hamlin' orange tree fertilizer response in southwest Florida. Proc. Fla. State Hort. Soc. 103:12-16.

Obreza, T.A. 1993. Program fertilization for establishment of orange trees. J. Prod. Agr. 6:546552.

Obreza, T.A. and M.E. Collins. 2002. Common soils used for citrus production in Florida. Fla. Coop. Ext. Serv. SL193. 17 Sept. 2008. <http:// edis.ifas.ufl.edu/SS403>.

Obreza, T.A. and K.T. Morgan (eds.). 2008. Nutrition of Florida citrus trees. 2nd Ed. Fla. Coop. Ext. Serv. SL253. 17 Sept. 2008. <http://edis.ifas. ufl.edu/SS478>.

Paramasivam, S., A.K. Alva, K.H. Hostler, G.W Easterwood, and J.S. Southwell. 2000. Fruit nutrient accumulation of four orange varieties during fruit development. J. Plant Nutr. 23: 313-327.

Quaggio, J.A., H. Cantarella, and B. van Raij. 1998. Phosphorus and potassium soil test and nitrogen leaf analysis as a base for citrus fertilization. Nutrient Cycl. Agroecosyst. 52:67-74.

Rhue, R.D. and P.H. Everett. 1987. Response of tomatoes to lime and phosphorus on a sandy soil. Agron. J. 79:71-77.

Smith, P.F. 1954. Citrus nutrition. In: Childers, N.F. (ed.). Mineral nutrition of fruit crops. Rutgers Univ. Press, Somerville, NJ.

Soil and Plant Analysis Council, Inc. 1999. Soil analysis handbook of reference methods. Soil and Plant Analysis Council, Inc, Lincoln, NE.

Southern Extension and Research Activity Group. 1992. Plant analysis reference procedures for the southern region of the United States. Southern Coop. Series Bull. 368.

Spencer, W.F. 1963. Phosphorus fertilization of citrus. Fla. Agr. Expt. Sta. Bul. 653.

Systat Software, Inc. 2006. SigmaStat 3.5 user's manual. Systat Software, Inc., Point Richmond, CA.

Tucker, D.P.H., R.M. Davis, T.A. Wheaton, and S.H. Futch. 1990. A nutritional survey of southcentral, southwest, and east coast flatwoods citrus groves. Proc. Fla. State Hort. Soc. 103:324-327.

Wardowski, W., J. Soule, W. Grierson, and G. Westbrook. 1979. Florida citrus quality tests. Fla. Coop. Ext. Serv. Bul. 188.

Zhang, M.K., Z.L. He, D.V. Calvert, P.J. Stoffella, Y.C. Li, and E.M. Lamb. 2002. Release potential of phosphorus in Florida sandy soils in relation to phosphorus fractions and adsorption capacity. J. Environ. Sci. Health A37:793809. 